\title{
Evaluation of regional background particulate matter concentration based on vertical distribution characteristics
}

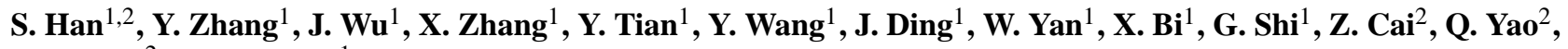 \\ H. Huang ${ }^{2}$, and Y. Feng ${ }^{1}$ \\ ${ }^{1}$ State Environmental Protection Key Laboratory of Urban Ambient Air Particulate Matter Pollution Prevention and Control, \\ College of Environmental Science and Engineering, Nankai University, Tianjin, 300071, China \\ ${ }^{2}$ Research Institute of Meteorological Science, Tianjin, 300074, China
}

Correspondence to: Y. Zhang (zhafox@126.com) and Y. Feng (fengyc@ nankai.edu.cn)

Received: 27 January 2015 - Published in Atmos. Chem. Phys. Discuss.: 27 May 2015

Revised: 15 September 2015 - Accepted: 18 September 2015 - Published: 7 October 2015

\begin{abstract}
Heavy regional particulate matter (PM) pollution in China has resulted in an important and urgent need for joint control actions among cities. It is advisable to improve the understanding of the regional background concentration of PM for the development of efficient and effective joint control policies. With the increase of height the influence of source emission on local air quality decreases with altitude, but the characteristics of regional pollution gradually become obvious. A method to estimate regional background $\mathrm{PM}$ concentration is proposed in this paper, based on the vertical characteristics of periodic variation in the atmospheric boundary layer structure and particle mass concentration, as well as the vertical distribution of particle size, chemical composition and pollution source apportionment. According to the method, the averaged regional background $\mathrm{PM}_{2.5}$ concentration in July, August and September 2009, being extracted from the original time series in Tianjin, was $40 \pm 20$, $64 \pm 17$ and $53 \pm 11 \mu \mathrm{g} \mathrm{m}^{-3}$, respectively.
\end{abstract}

\section{Introduction}

Atmospheric particulate matter (PM) has attracted considerable attention because it has been associated with many urban environmental problems, such as acid precipitation, decreasing visibility and climate change (Zeng and Hopke, 1989; Charlson et al., 1992; Schwartz et al., 1996; Chameides et al., 1999). PM has also been implicated in human mortality and morbidity (Dockery et al., 1993; Tie et al., 2009; Lagudu et al., 2011). Among the various sizes of atmospheric
$\mathrm{PM}, \mathrm{PM}_{2.5}$ (PM with aerodynamic diameter less than $2.5 \mu \mathrm{m}$ ) is considered to be of great significance due to its links to human respiratory health (Englert, 2004), regional-scale air pollution (Husar et al., 1981; Chameides et al., 1999), and potential acid rain enhancement (Cao et al., 2013).

The combination of rapid industrialization and urbanization has resulted in considerable environmental problems throughout China, especially in the clusters of cities (Shao et al., 2006). The coexistence of numerous air pollutants with high concentrations and the complicated interactions among them leads to the formation of an air pollution complex (Shao et al., 2006; Zhu et al., 2011). One of the major pollutants is PM (Tie et al., 2006; Liu et al., 2011; Chen et al., 2012; Han et al., 2013). The origin of PM is complex. It involves both primary emissions as well as secondary particle production due to chemical reactions in the atmosphere (Shi et al., 2011; Tian et al., 2013; Hu et al., 2013; Guo et al., 2013). With a lifetime of days to weeks in the lower atmosphere, $\mathrm{PM}_{2.5}$ can be transported thousands of kilometres (Hagler et al., 2006). The trans-boundary transport of $\mathrm{PM}_{2.5}$ and the gaseous precursors has significant influence on the regional background PM level in the cluster of cities. In order to study the regional-scale PM pollution and develop efficient joint control policies, it is necessary to improve understanding of regional background PM concentration.

Background concentration has been defined as concentration observed at a site "that is not affected by local sources of pollution" (WHO, 1980; Menichini et al., 2007). McKendry et al. (2006) defined background concentration as one of "those pollutants arising from local natural processes to- 
gether with those transported into an airshed from afar (the latter may be either natural or anthropogenic in origin)". Background concentration in this paper is defined to include collective contributions from regional anthropogenic and natural emissions and long-range transport.

Background concentrations are not constant because of meteorological variability, complexity of chemical reactions, as well as spatially and temporally varying emissions. Regional-scale PM pollution is associated with synoptic scenarios that induce the transfer, accumulation and the formation of pollutants at regional scales. Simply taking measurements at local scales is not well suited to adequately investigate the regional background concentration. There is always the possibility that the "air quality background monitoring station" is directly influenced by local emission sources and thus not truly representative of the background level (Tchepel et al., 2010). That is to say, background concentration can hardly be measured directly, so it is critical to choose representative and appropriate values. Usually, by setting some restrictions to identify and remove the influence of local pollution, background concentration can be determined indirectly. There are several studies mentioning the methods for determining the background concentration. These methods can be classified into four categories. (1) The physical methods identify the regional pollution process and local pollution process via synoptic situation, duration of the synoptic system, consistency of vertical wind, atmospheric stability, particle size distribution, etc., and then the data of the "background period" influenced by regional processes are selected (Pérez et al., 2008). (2) The chemical methods identify the regional process according to chemical composition in PM and synchronous observation of other pollutants, and then remove the data influenced by local processes (Menichini et al., 2007). (3) The statistical methods use discriminant analysis, cluster analysis and principal component analysis (PCA) to identify the data that characterize the regional background PM (Langford et al., 2009; Tchepel et al., 2010). (4) Numerical simulation methods use trajectory models and atmospheric dynamics-chemical coupled models to simulate the regional background pollution (Dreyer and Ebinghaus, 2009; Tchepel et al., 2010).

With the increase of height, the influence of source emission on local air quality decreases with altitude, but the characteristics of regional pollution gradually become obvious. Influenced by atmospheric dynamics and thermal effects, meteorological variables and pollutant measurements at different heights within the boundary layer could represent different horizontal scales of pollution. Sites at nearground height $(5-10 \mathrm{~m})$ are influenced extensively by human activities, and the data observed at these sites could represent the street scale. Impacts from local disturbance weaken with height gradually and observations at greater heights could represent larger horizontal scales. When the height increases to the top of the urban atmospheric boundary layer, observations can represent urban scales. Heights above the urban boundary layer could to some extent reflect the characteristics of regional scales. A tall tower is commonly used in observation of boundary layer meteorological, micrometeorological and atmospheric chemical variables, e.g. vertical profile and fluxes (Heintzenberg et al., 2008, 2013; Brown et al., 2013; Andreae et al., 2015). The footprint concept is capable of linking observed data collected at the different height levels of the tower to spatial context. The integral beneath the footprint function expresses the total surface influence on the signal measured by the sensor at a height above the surface (Schmid, 2002; Ding et al., 2005; Foken and Nappo, 2008). Three main factors affect the size and shape of flux footprint: increase in measurement height, decrease in surface roughness, and change in atmospheric stability from unstable to stable leading to an increase in size of the footprint (https://en.wikipedia.org/wiki/Flux_footprint). Combined information from meteorological data and simultaneous aerosol measurements at the different levels of the tower have made it possible to gain insights into the transport of aerosols and their vertical distributions which strongly depend on meteorological conditions, boundary layer dynamics and physiochemical processes (Guinot et al., 2006; Pal et al., 2014). In this paper, the periodic variation in the atmospheric boundary layer structure and PM mass concentrations, as well as the vertical distribution characteristics of particle size, chemical composition and pollution sources, were studied to characterize the regional pollution contribution. On this basis, the height above which there is relatively less influence by local pollution emission can be determined and the regional background PM concentration can be extracted from the observation data and estimated by mathematical methods.

\section{Data sources and treatment}

\subsection{Observation site}

The data used in this study were collected at a $255 \mathrm{~m}$ meteorological tower which is located at the atmospheric boundary layer observation station (WMO Id. No. 54517, $39^{\circ} 04^{\prime} 29.4^{\prime \prime} \mathrm{N}, 117^{\circ} 12^{\prime} 20.1^{\prime \prime} \mathrm{E}$ ) in Tianjin, China, where there is a residential and traffic mixing area. There are no industrial pollution sources near the site. Tianjin is adjacent to the BoHai Sea and situated in the eastern part of the BeijingTianjin-Hebei area, one of the most heavily polluted areas in China. Tianjin covers an area of $11300 \mathrm{~km}^{2}$ and has a population of 8 million. Due to rapid industrialization and urbanization in recent years, air pollution has become a serious problem in this city.

\subsection{Observation method and data treatment}

Horizontal wind speed, wind direction, and temperature were measured at 15 platforms $(5,10,20,30,40,60,80,100$, $120,140,160,180,200,220$ and $250 \mathrm{~m}$ ) every $10 \mathrm{~s}$ and 
averaged hourly. Three-dimensional ultrasonic anemometers (CAST-3D) were mounted at 40, 120 and $220 \mathrm{~m}$ to measure the turbulent fluxes. Hourly meteorological data (WMO Id. No. 54517) in the year of 2009 were used in this paper.

Mass concentrations of $\mathrm{PM}_{2.5}$ were measured using ambient particulate monitor chemiluminescence (TEOMRRP1400a) at four different heights (2, 40, 120, and $220 \mathrm{~m}$ ) from 1 July to 30 September 2009. The monitor's data output consists of 1 and $24 \mathrm{~h}$ average mass concentration updated every $10 \mathrm{~min}$ and on the hour, with the precision of $\pm 1.5 \mu \mathrm{g} \mathrm{m}^{-3}$ ( $1 \mathrm{~h} \mathrm{avg}$ ) and $\pm 0.5 \mu \mathrm{g} \mathrm{m}^{-3}$ (24h avg) respectively. The accuracy of mass measurement is $\pm 0.75 \%$.

In order to study the vertical characteristics of PM chemical composition and sources, $24 \mathrm{~h} \mathrm{PM}_{10}$ filter samples were collected from local Beijing time 08:00 to 07:00 GMT + 8:00 the next day using medium-volume $\mathrm{PM}_{10}$ samplers $(\mathrm{TH}-$ 150, Wuhan Tianhong Intelligence Instrumentation Facility) at the heights of 10,40,120, and $220 \mathrm{~m}$ from 24 August to 12 September 2009. The sampler has a system of automatic constant-flow control. Flow rate of sampling in this study is $100 \mathrm{~L} \mathrm{~min}^{-1}$, and the relative error of flow is less than $3 \%$. At each height, $\mathrm{PM}_{10}$ filter samplings were equipped with two samplers in parallel: one is for chemical analysis of inorganic composition on polypropylene filters $(90 \mathrm{~mm}$ in diameter, Beijing Synthetic Fiber Research Institute, China) and the other is for organic composition analyses on quartz-fibre filters (90 mm in diameter, 2500QAT-UP, Pall Life Sciences).

Before and after sampling, filters were conditioned for $48 \mathrm{~h}$ in darkened desiccators prior to gravimetric determination. The filters were weighed on a electronic microbalance (AX205, Mettler-Toledo, LLC, with a $\pm 0.01 \mathrm{mg}$ sensitivity) in a clean room under constant temperature $\left(20 \pm 1^{\circ}\right)$ and $\mathrm{RH}$ $(40 \pm 3 \%)$. Samples were stored air-tight in a refrigerator at about $4^{\circ}$ before chemical analyses.

Elements ( $\mathrm{Si}$, Ti, Al, Mn, Ca, Mg, Na, K, Cu, Zn, Pb, Cr, $\mathrm{Ni}, \mathrm{Co}, \mathrm{Fe}$, and $\mathrm{V}$ ) were analysed by Inductively Coupled Plasma atomic emission spectroscopy (ICP 9000 (N+M) Thermo Electron Corporation, USA). Blank filters were processed simultaneously with sample filters. Ultrapure water, both unfiltered and filtered, and nitric acid were also analysed. The average element values in the blanks were subtracted from those obtained for each sample filter; $10 \%$ of total samples were analysed in duplicate to verify sample homogeneity. The precision and accuracy were checked by analysis of an intermediate calibration solution. Extraction efficiencies were evaluated by analysis of the certified reference material from the National Research Center for CRM. The recovery value was between 85 and $110 \%$. Calibration check was performed to ensure a relative error of no more than $2 \%$ for major elements and $5 \%$ for trace elements.

Water-soluble ions $\left(\mathrm{NH}_{4}^{+}, \mathrm{Cl}^{-}, \mathrm{NO}_{3}^{-}\right.$, and $\left.\mathrm{SO}_{4}^{2-}\right)$ were analysed by ion chromatography (DX-120, Dionex Ltd., USA) after extraction by deionized water. External calibration was employed to quantify the ion concentrations. A calibration check with external standards was performed to en- sure a relative error of no more than $10 \%$. The uncertainty contributions of the calibration curve, calibration solution and repetitive measurement for unknown sample were taken into account. The expanded uncertainty was $3.8 \%$ with a coverage factor of $k=2$.

The thermal optical carbon analyser (Desert Research Institute (DRI) Model 2001, Atmoslytic Inc., Calabasas, CA, USA) was used to measure organic carbon (OC) and elemental carbon (EC). The heating process can be found in the IMPROVE_A protocol (Chow et al., 2010, 2011; Cao et al., 2003). Field blank and lab blank were considered and all sampling concentrations were revised by blank concentration. The uncertainty contributions of the calibration curve, calibration solution and repetitive measurement for unknown sample were taken into account. The expanded uncertainty was $7.6 \%$ with a coverage factor of $k=2$.

\section{Vertical variation characteristics of urban boundary structure}

\subsection{Thermal and dynamic characteristics in surface layer}

Surface layer has a remarkable effect on the diffusion of air pollutants. This layer is strongly affected by human behaviour on the ground. Figure 1 presents the diurnal variation of averaged wind speed in four seasons at different heights in Tianjin. The four seasons were designated as March-May for spring, June-August for summer, September-November for autumn, and December-February for winter. Diurnal variation patterns of wind speed were similar in each season. The wind speed is high in daytime and low at night below $100 \mathrm{~m}$, whereas there is low wind speed in the daytime and high wind speed at night above $100 \mathrm{~m}$.

Figure 2 shows the vertical profile of wind speed and temperature in low atmosphere under different stability. The gradient Richardson number $(R i)$ was used for classifying the atmospheric stability conditions:

$R i=\frac{g}{\bar{T}}\left[\frac{\Delta T}{\sqrt{z_{1} z_{2}} \ln \frac{z_{2}}{z_{1}}}+r_{\mathrm{d}}\right] \times\left[\frac{\sqrt{z_{1} z_{2}} \ln \frac{z_{2}}{z_{1}}}{\Delta u}\right]$,

where $\Delta T=T_{2}-T_{1}, \Delta u=u_{2}-u_{1}, T_{2}$ and $T_{1}$ are the measured temperatures at the height of $z_{2}$ and $z_{1}, \bar{T}$ is the averaged temperature in the layer between level $z_{2}$ and $z_{1}, u_{2}$ and $u_{1}$ are the measured wind speed at levels $z_{2}$ and $z_{1}, g$ is the gravitational acceleration, and $r_{\mathrm{d}}$ is the dry adiabatic lapse rate. According to the values of $R i$, three different conditions can be distinguished: $R i \geq 0.1$ for stable condition, $-0.1<R i<0.1$ for neutral condition, and $R i \leq-0.1$ for unstable condition.

The atmospheric layer at $100-150 \mathrm{~m}$ is considered as a transition layer, the variation patterns of temperature and wind speed with height were different compared with the upper and lower layers. A weak vertical gradient in the tem- 

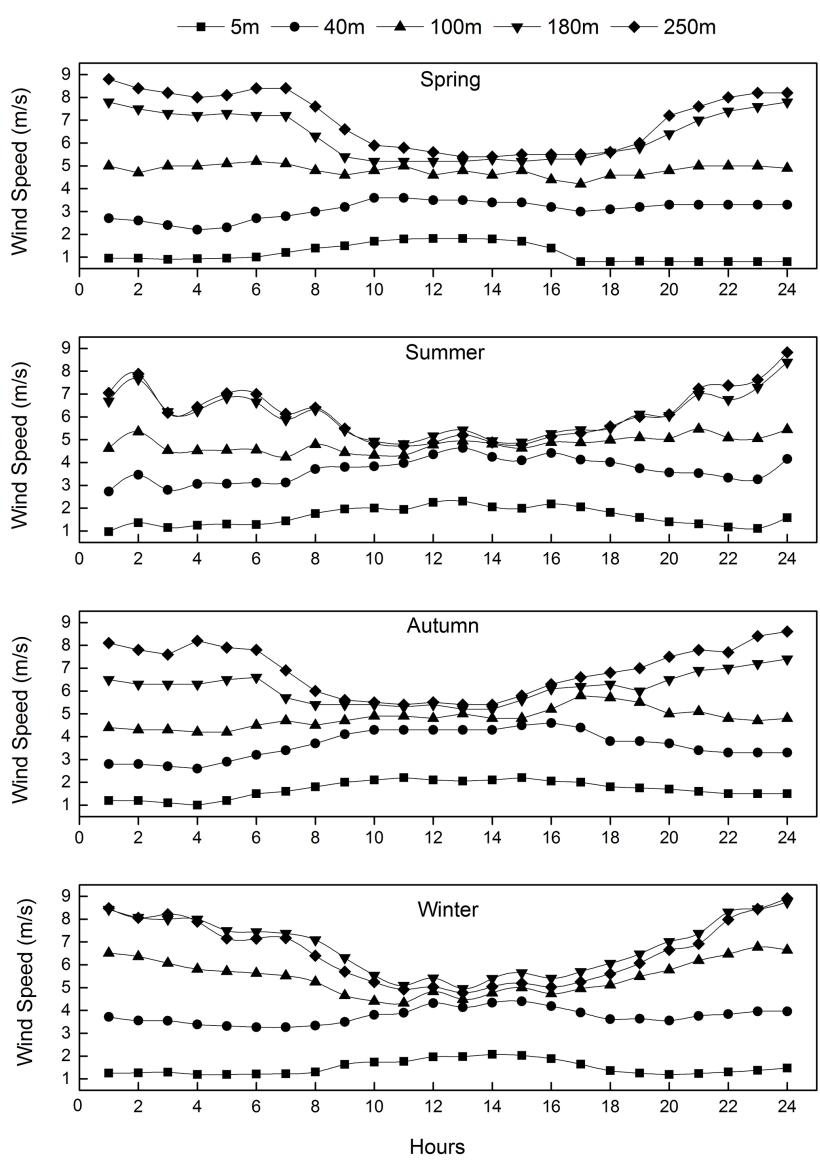

Figure 1. Diurnal variation of averaged wind speed in each season at different heights.

perature profile was observed over $100 \mathrm{~m}$. Similarly, a small vertical gradient in wind speed was found over $150 \mathrm{~m}$.

\subsection{The height of nocturnal planetary boundary and vertical variation of turbulent intensity}

The height of the planetary boundary layer (PBL), indicating the range of pollutants diffused by thermal turbulence in the vertical direction (Kim et al., 2007; Lena and Desiato, 1999), can be calculated by wind and temperature profiles (Seibert et al., 2000; Han et al., 2009). Based on the temperature profile observed at the tower, the vertical gradient of temperature was calculated as

$$
\frac{\Delta T}{\Delta Z}=\frac{T(z+1)-T(z)}{Z(z+1)-Z(z)}
$$

where $T(z+1)$ and $T(z)$ represent the measured temperatures at levels $z+1$ and $z$, and $Z(z+1)$ and $Z(z)$ represent the altitudes at levels $z+1$ and $z$. The height of the nocturnal planetary boundary layer (NPBL) is determined by the bottom of the inversion, i.e. the layer in which the temperature profile has a positive gradient. As shown in Fig. 3, the sea-
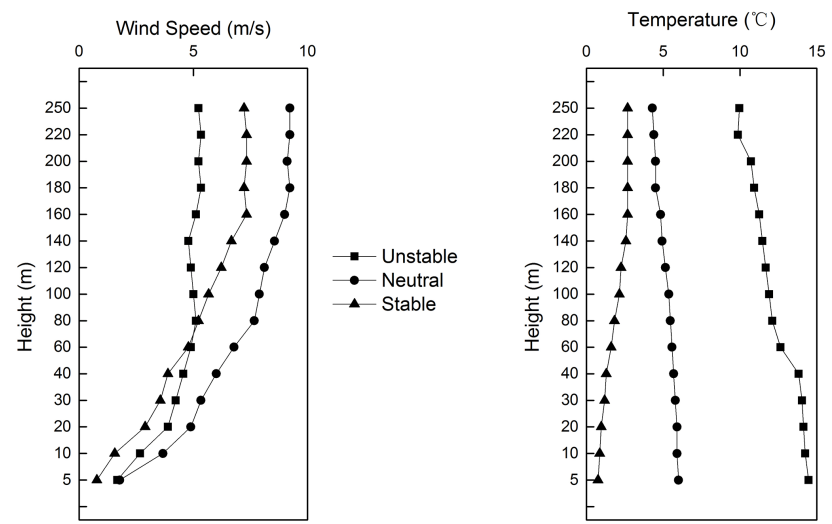

Figure 2. Vertical distribution profile of average wind speed and temperature in low atmosphere under different stability conditions.

sonal variation of the NPBL height is generally small, with seasonal averaged NPBL height ranging from 114 to $142 \mathrm{~m}$.

In this study, hourly averaged $\mathrm{PM}_{2.5}$ concentration measurement and $24 \mathrm{~h} \mathrm{PM}_{10}$ filter sampling were conducted at four platforms. The heights of the first and second platform are inside the NPBL, the third platform is located at the top of the NPBL, and the fourth platform is generally outside the NPBL. Due to the dynamical stability of the NPBL, air pollutants in the surface layer are normally trapped inside the NPBL and rarely mix with the pollutants outside the NPBL. Very different distribution characterizations of PM were measured inside and outside the NPBL (see Sect. 4).

Based on the observation data from the three-dimensional ultrasonic anemometers, the turbulent intensity were calculated. As a whole, the averaged diurnal variations of turbulent intensity in each season (Fig. S1 in the Supplement) were reflecting the same trends. The diurnal peaks appeared later and turbulent intensity was slightly weaker in winter than in other seasons. Averaged diurnal variation of turbulent intensity at different heights during the year of 2009 is shown in Fig. 4. Three-dimensional components of turbulent intensity decreased with increase in height. From the height of 40 to $120 \mathrm{~m}$, the $u, v$ and $w$ components of turbulent intensity reduced by 27,32 and $21 \%$, respectively. From 120 to $220 \mathrm{~m}$, the $u, v$ and $w$ components reduced by 12,13 and $15 \%$, respectively. The descending trend is more obvious from 40 to $120 \mathrm{~m}$ than from 120 to $220 \mathrm{~m}$. This indicates that there were full vertical and horizontal turbulence exchanges below $120 \mathrm{~m}$ of the tower, but relatively weaker exchanges over $120 \mathrm{~m}$.

\section{Vertical distribution of $\mathbf{P M}_{2.5}$ mass concentration}

The diurnal variation of $\mathrm{PM}_{2.5}$ mass concentrations during the period from 1 July to 30 September 2009 is shown in Fig. 5. The vertical variation patterns of $\mathrm{PM}_{2.5}$ concentrations were quite different during the daytime and night re- 


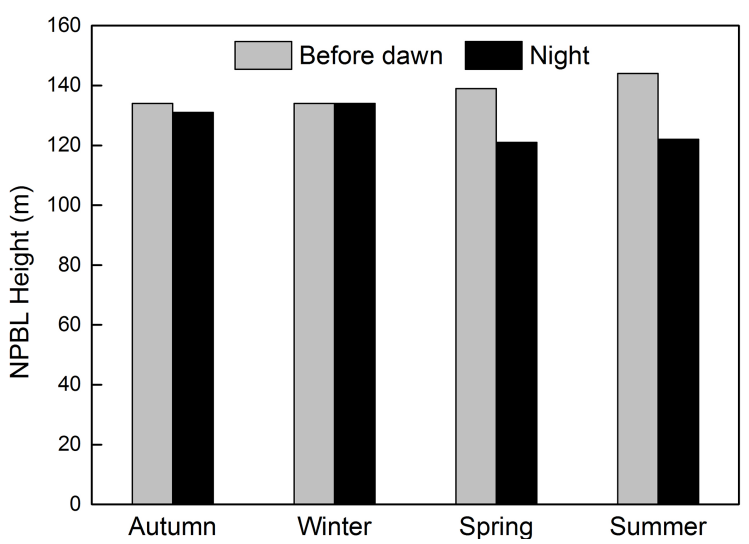

Figure 3. Averaged NPBL height in each season (before dawn 01:00-07:00; at night: 19:00-24:00 GMT + 8:00).

sulting from a combination of diurnal variations of emissions and PBL. After sunrise, the PBL height starts to rapidly increase, pollutants near the ground gradually diffuse upward and the $\mathrm{PM}_{2.5}$ concentration near the surface gradually decreases. At noon, the mixing layer is fully developed with the averaged PBL height being about 1000-1200 m. Among these four platforms $(2,40,120$ and $220 \mathrm{~m}), \mathrm{PM}_{2.5}$ concentration at $220 \mathrm{~m}$ is the highest during noon and afternoon. In contrast, after 18:00 GMT + 8:00, the PBL height starts to rapidly decrease. The NPBL height generally ranges between 100 and $150 \mathrm{~m}$ (Fig. 3). At the first and second platform $(2,40 \mathrm{~m})$, the measured PM are normally inside of the NPBL. By contrast, the measurement platform at $220 \mathrm{~m}$ is generally outside the NPBL. Level $3(120 \mathrm{~m})$ is considered as being at the transition zone between the inside and outside of the NPBL. Due to the dynamical stability of the NPBL, the vertical mixing of pollutants between inside and outside of the NPBL is very weak. The surface emitted PM are normally trapped inside the NPBL, leading to the difference in the amount of aerosols below and above the NPBL. Among these four platforms, $\mathrm{PM}_{2.5}$ concentration at $220 \mathrm{~m}$ during the night is the lowest. This indicates that the observation value of $220 \mathrm{~m}$ at night is less affected by local sources of emission and is largely attributed to regional-scale pollution.

\section{Vertical distributions of $\mathrm{PM}_{10}$ concentration, composition and source apportionment}

\subsection{Vertical characteristics of $\mathbf{P M}_{10}$ concentration}

As mentioned in Sect. 2.2, $\mathrm{PM}_{10}$ filter samples were collected at the heights of 10, 40, 120 and $220 \mathrm{~m}$. The daily concentrations at each sampling height were $139 \pm 45,121 \pm 43$, $110 \pm 39$ and $79 \pm 37 \mu \mathrm{g} \mathrm{m}^{-3}$, respectively. These concentrations exhibited a general decreasing trend with the increase of height.
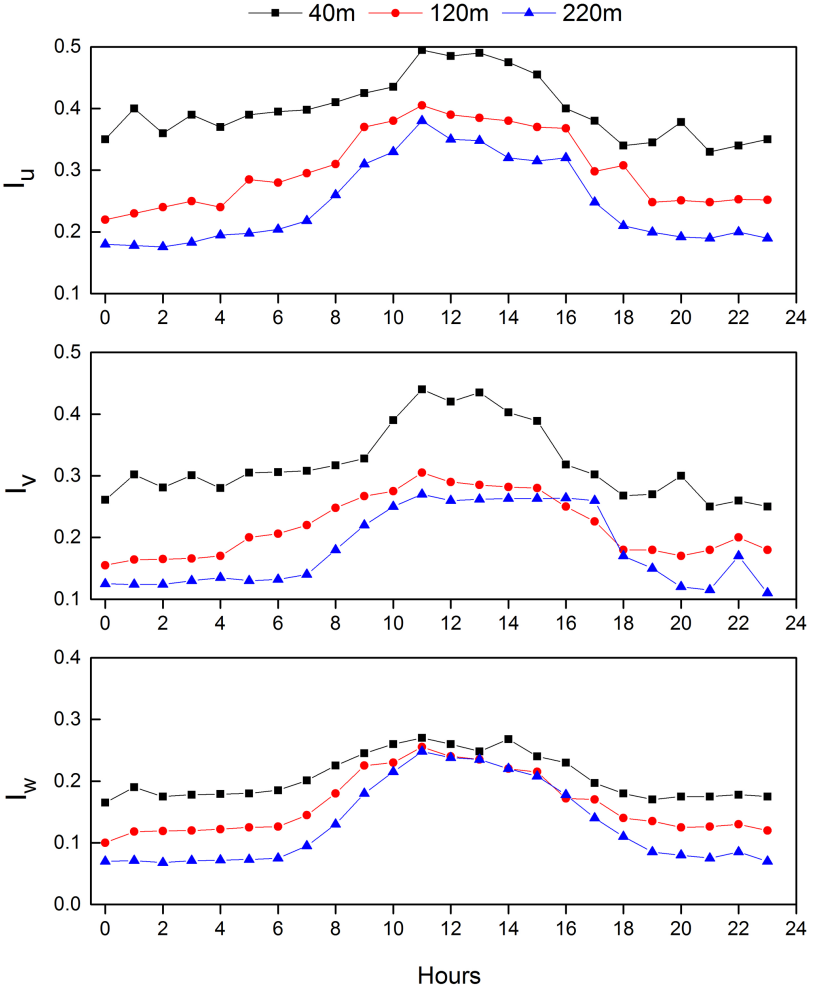

Figure 4. Averaged diurnal variation of three-dimensional components of turbulent intensity at different heights (longitudinal turbulent intensity $I_{u}$, lateral turbulent intensity $I_{v}$, vertical turbulent intensity $\left.I_{w}\right)$.

The height-to-height correlation coefficients of the variation of $\mathrm{PM}_{10}$ concentration were calculated and listed in Table 1 . All the pairwise correlation coefficients among 10, 40 and $120 \mathrm{~m}$ were higher than 0.9 . However, the correlation coefficients between $220 \mathrm{~m}$ and other heights were obviously low. These results suggest that the influences of local emissions and local meteorological diffusion conditions on $\mathrm{PM}_{10}$ concentrations are weaker at $220 \mathrm{~m}$ than at lower levels.

\subsection{Vertical characteristics of $\mathbf{P M}_{10}$ chemical composition}

Coefficient of divergence (CD) analysis (Wongphatarakul et al., 1998; Krudysz et al., 2009) was used in this study to assess vertical variability of chemical elements in $\mathrm{PM}_{10}$ filter samples collected at four heights. The CD values provide information on the degree of uniformity between sampling sites and is defined as

$\mathrm{CD}_{j k}=\sqrt{\frac{1}{p} \sum_{i=1}^{p}\left(\frac{x_{i j}-x_{i k}}{x_{i j}+x_{i k}}\right)^{2}}$,

where $x_{i j}$ is the average concentration of the $i$ th element at $j$ th height. The $j$ and $k$ represent the two sampling heights, 


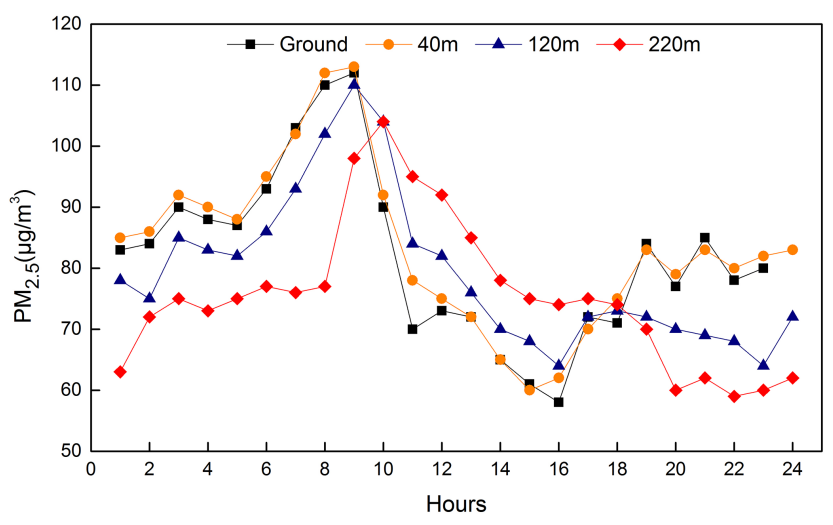

Figure 5. Vertical diurnal variation of $\mathrm{PM}_{2.5}$ mass concentrations during the period from 1 July to 30 September 2009.

and $p$ is the number of elements. When the species concentrations at two sampling sites were similar to each other, the $\mathrm{CD}$ values would approach 0 . On the other hand, as the two species concentrations diverge the $\mathrm{CD}$ value will approach 1 (Hwang et al., 2008).

The pair-wise CD values for four heights are shown in Table 2. The pair-wise $C D$ values among 10, 40 and $120 \mathrm{~m}$ are lower than 0.2 , illustrating that the element profiles of these three heights were similar to each other, while the $\mathrm{CD}$ values between $220 \mathrm{~m}$ and the other three levels were obviously high. This may have resulted from the fact that chemical elements in the $\mathrm{PM}_{10}$ filter samples collected at $220 \mathrm{~m}$ were mainly originated from regional-scale sources.

The concentration of chemical composition in ambient $\mathrm{PM}_{10}$ filter samples collected at four heights are shown in Table 3. $\mathrm{Al}, \mathrm{Si}, \mathrm{Ca}, \mathrm{OC}, \mathrm{EC}, \mathrm{Cl}^{-}, \mathrm{NO}_{3}^{-}$and $\mathrm{SO}_{4}^{2-}$ have higher concentration levels than other species. $\mathrm{Al}$ can be used as a source marker of coal combustion (Hopke, 1985); $\mathrm{Al}$ and $\mathrm{Si}$ are the markers of soil dust (Liu et al., 2003), Ca is mainly emitted from cement dust (Shi et al., 2009); EC can be identified as vehicle exhaust emission ( $\mathrm{Li}$ et al., 2004); $\mathrm{Cl}^{-}$is the marker for sea salt (Li et al., 2004); and $\mathrm{NO}_{3}^{-}$and $\mathrm{SO}_{4}^{2-}$ are the markers of secondary nitrate and sulfate (Liu et al., 2003). Higher concentrations were found at lower sampling heights for almost all species $\left(\mathrm{NO}_{3}^{-}\right.$had the highest value at $120 \mathrm{~m}$ ). Unlike the species concentration, the vertical distribution of species percentages (\%) shows different patterns. Similar fraction levels were observed at the four heights for $\mathrm{Al}$ and $\mathrm{Si}$. For $\mathrm{Ca}$ and $\mathrm{EC}$, higher values were observed at lower sampling sites. The percentages of OC at $220 \mathrm{~m}$ were obviously higher than those at $120 \mathrm{~m}$. This might imply that the influence of local sources on OC was weaker and the contributions from secondary and regional sources were larger at $220 \mathrm{~m}$. The OC / EC ratios increased gradually from 10 to $220 \mathrm{~m}$. This might be due to a relatively higher percentage of SOC in OC at higher heights as a result of the formation and regional transport of SOC (Strader et al., 1999). Similarly, the higher sampling sites obtained higher fractions (\%)
Table 1. Height-to-height correlation coefficient of $\mathrm{PM}_{10}$ concentration.

\begin{tabular}{lrrrr}
\hline & $10 \mathrm{~m}$ & $40 \mathrm{~m}$ & $120 \mathrm{~m}$ & $220 \mathrm{~m}$ \\
\hline $10 \mathrm{~m}$ & 1.0 & & & \\
$40 \mathrm{~m}$ & 0.96 & 1.0 & & \\
$120 \mathrm{~m}$ & 0.91 & 0.94 & 1.0 & \\
$220 \mathrm{~m}$ & 0.72 & 0.76 & 0.85 & 1.0 \\
\hline
\end{tabular}

Table 2. Pair-wise CD values at different heights.

\begin{tabular}{lccc}
\hline & $10 \mathrm{~m}$ & $40 \mathrm{~m}$ & $120 \mathrm{~m}$ \\
\hline $40 \mathrm{~m}$ & 0.10 & & \\
$120 \mathrm{~m}$ & 0.15 & 0.11 & \\
$220 \mathrm{~m}$ & 0.33 & 0.30 & 0.59 \\
\hline
\end{tabular}

for $\mathrm{NO}_{3}^{-}$and $\mathrm{SO}_{4}^{2-}$ (the highest percentage of $\mathrm{NO}_{3}^{-}$was observed at $120 \mathrm{~m}$ ). These trends suggest that the impact of primary sources from the ground decreased with the increase of height, while the impact of secondary sources mainly influenced by regional sources becomes more prominent.

\subsection{Vertical characteristics of $\mathbf{P M} 10$ sources}

In order to understand the vertical characteristics of $\mathrm{PM}_{10}$ sources, the chemical mass balance (CMB) model was applied for source apportionment at all four sampling heights. The CMB model, a useful receptor model, has been extensively used to estimate source categories and contributions to the receptor based on the balance between sources and the receptor (Chow et al., 2007; Watson et al., 2008). Further details of CMB can be found in the relative literature (Watson et al., 1984, 2002; USEPA, 2004). The data set of chemical composition in the $\mathrm{PM}_{10}$ samples during the measurement period and the source profiles reported in our previous works (Bi et al., 2007) were used in the CMB modelling.

Six source categories (coal combustion, crustal dust, cement dust, vehicle exhaust, secondary sulfate and secondary nitrate) and their source contributions $\left(\mu \mathrm{g} \mathrm{m}^{-3}\right)$ and percentage contributions (\%) estimated by the CMB model are listed in Table 4. The estimated source contributions $\left(\mu \mathrm{g} \mathrm{m}^{-3}\right)$ of all the sources showed a downward trend with the increase of height, whereas the percentage contributions (\%) of secondary sources (secondary sulfate and nitrate) presented a generally increasing trend with the increase in height. This might be due to the fact that for the secondary sources the particulate sizes are relatively smaller and the residence time of fine particle is longer. Generally, secondary sources can obtain a stronger influence from regional contributions $(\mathrm{Gu}$ et al., 2011). That is to say, PMs at higher heights obtain more regional contributions. To some extent, this could reflect characteristics at the regional scale. 
Table 3. The concentration of chemical composition in ambient $\mathrm{PM}_{10}$ at four height sampling sites $\left(\mu \mathrm{g} \mathrm{m}^{-3}\right)$.

\begin{tabular}{|c|c|c|c|c|c|c|c|c|}
\hline & \multicolumn{2}{|c|}{$10 \mathrm{~m}$} & \multicolumn{2}{|c|}{$40 \mathrm{~m}$} & \multicolumn{2}{|c|}{$120 \mathrm{~m}$} & \multicolumn{2}{|c|}{$220 \mathrm{~m}$} \\
\hline & Mean & $\mathrm{SD}^{*}$ & Mean & SD & Mean & SD & Mean & SD \\
\hline $\mathrm{Na}$ & 1.60 & 0.71 & 1.34 & 0.58 & 1.28 & 0.48 & 0.89 & 0.41 \\
\hline $\mathrm{Mg}$ & 1.51 & 0.54 & 1.29 & 0.92 & 0.99 & 0.52 & 0.54 & 0.36 \\
\hline $\mathrm{Al}$ & 6.3 & 2.5 & 5.9 & 2.1 & 4.9 & 1.7 & 4.0 & 1.7 \\
\hline $\mathrm{Si}$ & 8.5 & 4.6 & 6.8 & 2.9 & 6.4 & 2.8 & 4.9 & 2.8 \\
\hline $\mathrm{P}$ & ND & ND & ND & ND & ND & ND & ND & ND \\
\hline K & 1.41 & 0.72 & 1.02 & 0.44 & 1.11 & 0.68 & 0.70 & 0.35 \\
\hline $\mathrm{Ca}$ & 7.1 & 2.8 & 5.1 & 2.0 & 4.6 & 2.2 & 2.5 & 1.6 \\
\hline $\mathrm{Ti}$ & 0.23 & 0.12 & 0.19 & 0.12 & 0.24 & 0.20 & 0.29 & 0.53 \\
\hline V & ND & ND & ND & ND & ND & ND & ND & ND \\
\hline $\mathrm{Cr}$ & 0.04 & 0.03 & 0.04 & 0.03 & 0.05 & 0.04 & 0.04 & 0.04 \\
\hline $\mathrm{Mn}$ & 0.09 & 0.05 & 0.06 & 0.03 & 0.06 & 0.03 & 0.04 & 0.02 \\
\hline $\mathrm{Fe}$ & 2.51 & 1.22 & 2.08 & 1.21 & 1.92 & 1.09 & 1.09 & 0.80 \\
\hline $\mathrm{Ni}$ & 0.01 & 0.02 & 0.01 & 0.01 & 0.02 & 0.03 & 0.03 & 0.05 \\
\hline Co & 0.01 & ND & ND & ND & ND & ND & 0.01 & 0.01 \\
\hline $\mathrm{Cu}$ & 0.20 & 0.17 & 0.14 & 0.22 & 0.09 & 0.13 & 0.02 & 0.03 \\
\hline $\mathrm{Zn}$ & 0.69 & 0.32 & 0.60 & 0.31 & 0.55 & 0.28 & 0.27 & 0.16 \\
\hline $\mathrm{Br}$ & ND & ND & ND & ND & ND & ND & ND & ND \\
\hline $\mathrm{Ba}$ & ND & ND & ND & ND & ND & ND & ND & ND \\
\hline $\mathrm{Pb}$ & 0.06 & 0.06 & 0.06 & 0.06 & 0.05 & 0.05 & 0.03 & 0.03 \\
\hline $\mathrm{OC}^{*}$ & 13.5 & 6.2 & 10.8 & 4.6 & 9.6 & 3.8 & 7.3 & 3.1 \\
\hline $\mathrm{EC}^{*}$ & 7.0 & 2.2 & 5.3 & 2.0 & 4.4 & 1.8 & 3.0 & 1.6 \\
\hline $\mathrm{NH}_{4}^{+}$ & 6.2 & 3.5 & 6.3 & 3.4 & 6.9 & 3.1 & 5.7 & 4.0 \\
\hline $\mathrm{Cl}^{-}$ & 6.4 & 5.3 & 5.6 & 4.1 & 5.0 & 3.0 & 1.7 & 1.2 \\
\hline $\mathrm{NO}_{3}^{-}$ & 18.0 & 12.5 & 16.9 & 10.9 & 18.9 & 10.1 & 13.3 & 11.4 \\
\hline $\mathrm{SO}_{4}^{2-}$ & 27.4 & 20.6 & 26.1 & 17.5 & 25.3 & 16.4 & 19.7 & 16.2 \\
\hline $\mathrm{OC} / \mathrm{EC}$ & 1.91 & 2.79 & 2.03 & 2.26 & 2.20 & 2.10 & 2.40 & 1.90 \\
\hline $\mathrm{PM}_{10}$ & 140 & 48 & 120 & 44 & 108 & 41 & 80 & 39 \\
\hline
\end{tabular}

* SD: standard deviation; OC: organic carbon; EC: element carbon.

\section{Vertical variation of periodicity for the time series of $\mathbf{P M}_{2.5}$ concentrations}

The periodic characteristics of particulate concentration and meteorological variables can reflect different scales of atmospheric processes. In this paper, the vertical variation period of $\mathrm{PM}_{2.5}$ mass concentrations are analysed.

A time series of atmospheric pollutant concentration can be decomposed into baseline and short-term components. Using the filtering method, short-term fluctuations associated with the influence of local-scale pollution and dispersion conditions can be extracted from the original measurements. After the removal of local-scale effects, the time series of pollutant concentrations can be reconstructed to reflect the regional-scale influence.

\subsection{Filtering method}

The wavelet transform can be used to analyse time series that contain nonstationary signals at many different frequencies. In this paper, we chose the Morlet wavelet which is extensively used in studies of climate change and turbulence power spectrum analysis (Torrence and Compo, 1998). The normalization mother wavelet is

$\psi_{0}(\eta)=\pi^{-1 / 4} e^{i \omega_{0} \eta} e^{-\eta^{2} / 2}$,

where $\eta$ is the nondimensional time parameter and $\omega_{0}$ is the nondimensional frequency. The wavelet filter time series over a set of scales can be calculated by

$x_{n}=\frac{\delta j \delta t^{1 / 2}}{C_{\delta} \psi_{0}(0)} \sum_{j=0}^{J} \frac{R\left\{W_{n}\left(s_{j}\right)\right\}}{s_{j}^{1 / 2}}$,

where $\delta j$ is the spacing between the discrete scales, and $\delta t$ is the sampling interval. $S_{j}$ is a set of scales related to the frequency $\omega . C_{\delta}$ and $\psi_{0}(0)$ are both constants:

$\omega=\frac{\omega_{0}+\sqrt{2+\omega_{0}^{2}}}{4 \pi s}$.

The reconstruction then gives 
Table 4. Source contributions and percentage contributions at four different heights.

\begin{tabular}{llrrrrrrr}
\hline & & $\begin{array}{r}\text { Coal } \\
\text { combustion }\end{array}$ & $\begin{array}{r}\text { Crustal } \\
\text { dust }\end{array}$ & $\begin{array}{r}\text { Cement } \\
\text { dust }\end{array}$ & $\begin{array}{r}\text { Vehicle } \\
\text { exhaust }\end{array}$ & $\begin{array}{r}\text { Secondary } \\
\text { sulfate }\end{array}$ & $\begin{array}{r}\text { Secondary } \\
\text { nitrate }\end{array}$ & TOT \\
\hline Contribution & $10 \mathrm{~m}$ & 17 & 16 & 14 & 20 & 34 & 23 & 140 \\
$\left(\mu \mathrm{g} \mathrm{m}^{-3}\right)$ & $40 \mathrm{~m}$ & 16 & 13 & 10 & 17 & 33 & 21 & 120 \\
& $120 \mathrm{~m}$ & 14 & 12 & 8 & 15 & 32 & 24 & 108 \\
& $220 \mathrm{~m}$ & 12 & 9 & 4 & 12 & 25 & 17 & 80 \\
\hline Percentage & $10 \mathrm{~m}$ & 12 & 11 & 10 & 14 & 24 & 16 & 88 \\
$(\%)$ & $40 \mathrm{~m}$ & 13 & 11 & 8 & 14 & 27 & 18 & 90 \\
& $120 \mathrm{~m}$ & 13 & 11 & 8 & 14 & 29 & 22 & 97 \\
& $220 \mathrm{~m}$ & 14 & 11 & 5 & 15 & 31 & 21 & 97 \\
\hline
\end{tabular}

Table 5. Values of the parameters of the Morlet transform in this study.

\begin{tabular}{cccccc}
\hline$C_{\delta}$ & $\psi_{0}$ & $s_{0}$ & $\delta t$ & $\delta j$ & $\omega_{0}$ \\
\hline 0.776 & $\pi^{-1 / 4}$ & $2 \delta t$ & 2 & 0.25 & 6.0 \\
\hline
\end{tabular}

$C_{\delta}=\frac{\delta j \delta t^{1 / 2}}{\psi_{0}(0)} \sum_{j=0}^{J} \frac{R\left\{W_{\delta}\left(s_{j}\right)\right\}}{s_{j}^{1 / 2}}$.

According to the conservation of total energy under the wavelet transform and the equivalent of Parseval's theorem for wavelet analysis, the variance of the time series is

$\sigma^{2}=\frac{\delta j \delta t}{C_{\delta} N} \sum_{n=0}^{N-1} \sum_{j=0}^{J} \frac{\left|W_{n}\left(s_{j}\right)\right|^{2}}{s_{j}}$.

Both Eqs. (7) and (8) should be used to check wavelet routines for accuracy and to ensure that sufficiently small values of $s_{0}$ and $\delta j$ have been chosen. The values of the above parameters are given in Table 5.

As discussed above, the wavelet transform is essentially a bandpass filter. By summing over a subset of the scales in Eq. (5), a wavelet-filtered time series can be constructed as follows:

$x_{n}^{\prime}=\frac{\delta j \delta t^{1 / 2}}{C_{\delta} \psi_{0}(0)} \sum_{j=j_{1}}^{j_{2}} \frac{R\left\{W_{n}\left(s_{j}\right)\right\}}{s_{j}^{1 / 2}}$.

This filter has a response function given by the sum of the wavelet functions between scale $j_{1}$ and $j_{2}$.

\subsection{Fluctuation spectrum analysis of $\mathbf{P M}_{2.5}$ concentration time series at different heights}

The fluctuation spectrum distribution of hourly mass concentrations of $\mathrm{PM}_{2.5}$ on the ground and at the height of 2, 40, 120 and $220 \mathrm{~m}$ have been analysed in this paper. Missing data in the time series were computed by interpolation.
Because of low proportions and unconcentrated distributions in the missing data, little human interference was applied to the spectral composition of the original time series. For better comparison, normalization (standard variance 1 , mean 0 ) of the original time series was necessary prior to power spectrum analysis.

The local and global wavelet power spectrum contours for the time series of $\mathrm{PM}_{2.5}$ concentrations at different heights in August are shown in Fig. 6. Contours are expressed as $\log _{2}\left(\left|W_{n}(s)\right|^{2}\right)$ because of large magnitudes. The area inside the thick black solid line passes the red noise standard spectral test with the $5 \%$ significance level. The area outside the blue dotted line was excluded from analysis because of poor reliability from the cone of influence, where edge effects become important. The global wavelet spectrum $\overline{W^{2}}(s)$, which reflects characteristics of the pollutant concentration time series in the frequency domain, was obtained by calculating the average of local wavelet spectra $\left|W_{n}(s)\right|^{2}$ over the entire sampling time domain. The solid line is the global wave spectrum for the corresponding time series. The dashed line is the $5 \%$ significance level, the upper area of which passes the red noise standard spectral test at the $5 \%$ significance level.

The global wavelet power spectrum of $\mathrm{PM}_{2.5}$ mass concentration shows that fluctuations of 6-10 days (related to weather process and regional-scale pollution) are significant at each observation height, while fluctuations of $12-24 \mathrm{~h}$ (mainly concerned with the daily variation of atmospheric boundary layer and local pollution emissions by human activities) are significant only at ground level. For the fluctuations of $\mathrm{PM}_{2.5}$ mass concentration, wave energy of 6-10-day period reduces with the increase of height. In terms of the local power spectrum, a $12-24 \mathrm{~h}$ period can be observed in a few days on the ground. But with the increase of height, the power of the $12-24 \mathrm{~h}$ period became weaker, only $10-30 \%$ of that on the ground. 

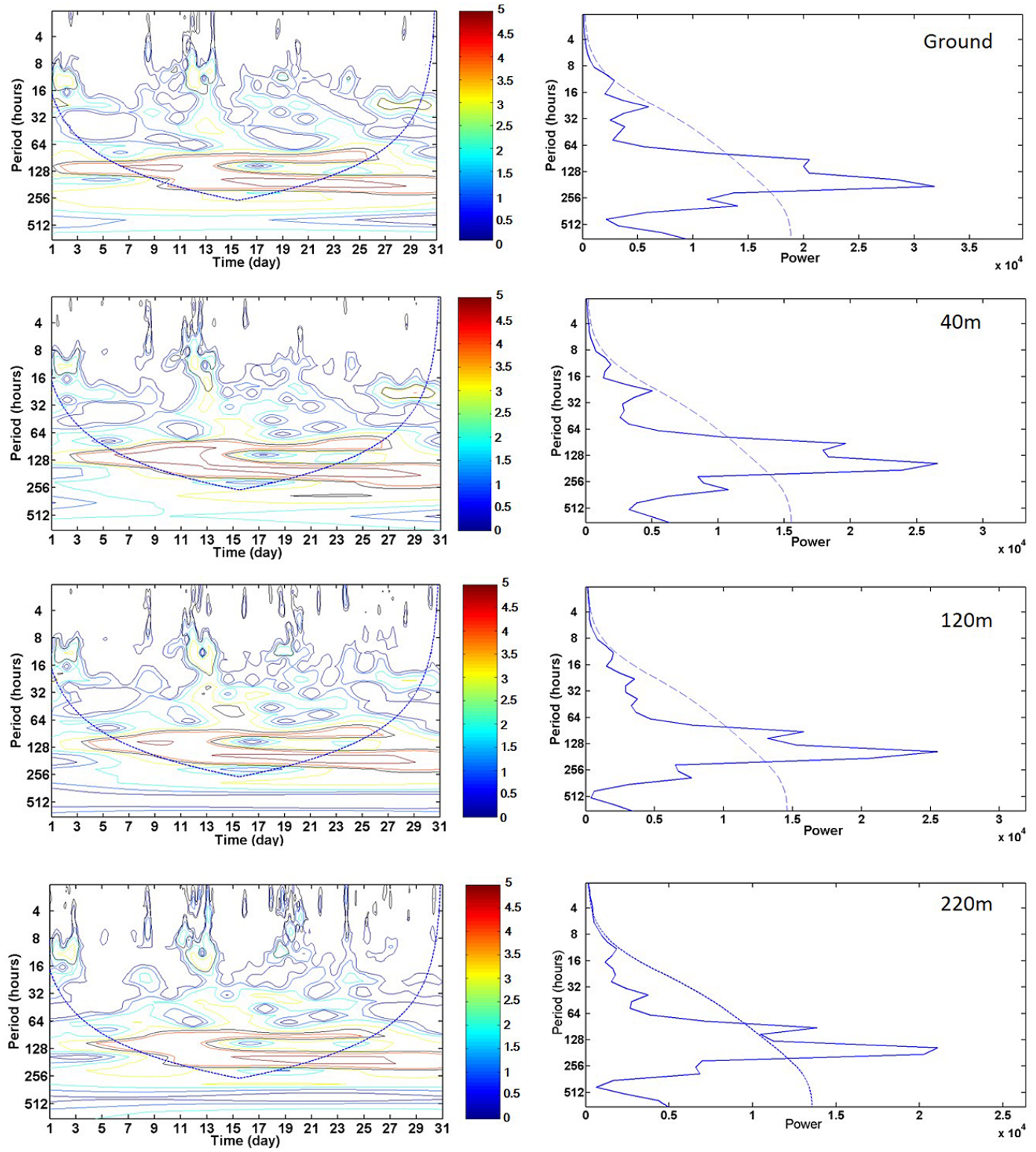

Figure 6. Local (left panels) and global (right panels) wavelet power spectrum of $\mathrm{PM}_{2.5}$ mass concentration at different heights in August 2009.

\section{Determination of regional background concentration of particulate matter}

Regional PM background concentration can hardly be measured directly. Original PM concentration time series measured on the ground reflect a combination of influence from local pollution and regional-scale pollution. This study is expected to establish an approach to characterize the regional pollution contribution and to evaluate regional background PM concentration levels. According to the above research concerning the vertical distribution characteristics of particle size, chemical composition and pollution sources, the atmospheric boundary layer structure, as well as the fluctu- ation power spectrum analysis of particle mass concentration, the measurement height (influenced relatively less by local pollution emission) was determined and impacts from local-scale pollution on the short-term fluctuations removed from the original PM concentration by wavelet transformation. The nocturnal $\mathrm{PM}_{2.5}$ mass concentration time series with the 6-10-day period at the observation height of $220 \mathrm{~m}$ was extracted to characterize the regional background concentration, which is mainly associated with the regional-scale pollution within $10^{2} \mathrm{~km}$ of the measurement tower.

Time series of $\mathrm{PM}_{2.5}$ hourly concentration before and after the filtering is presented in Fig. 7. Due to short-term fluctuations of pollution emission and local diffusion conditions, 

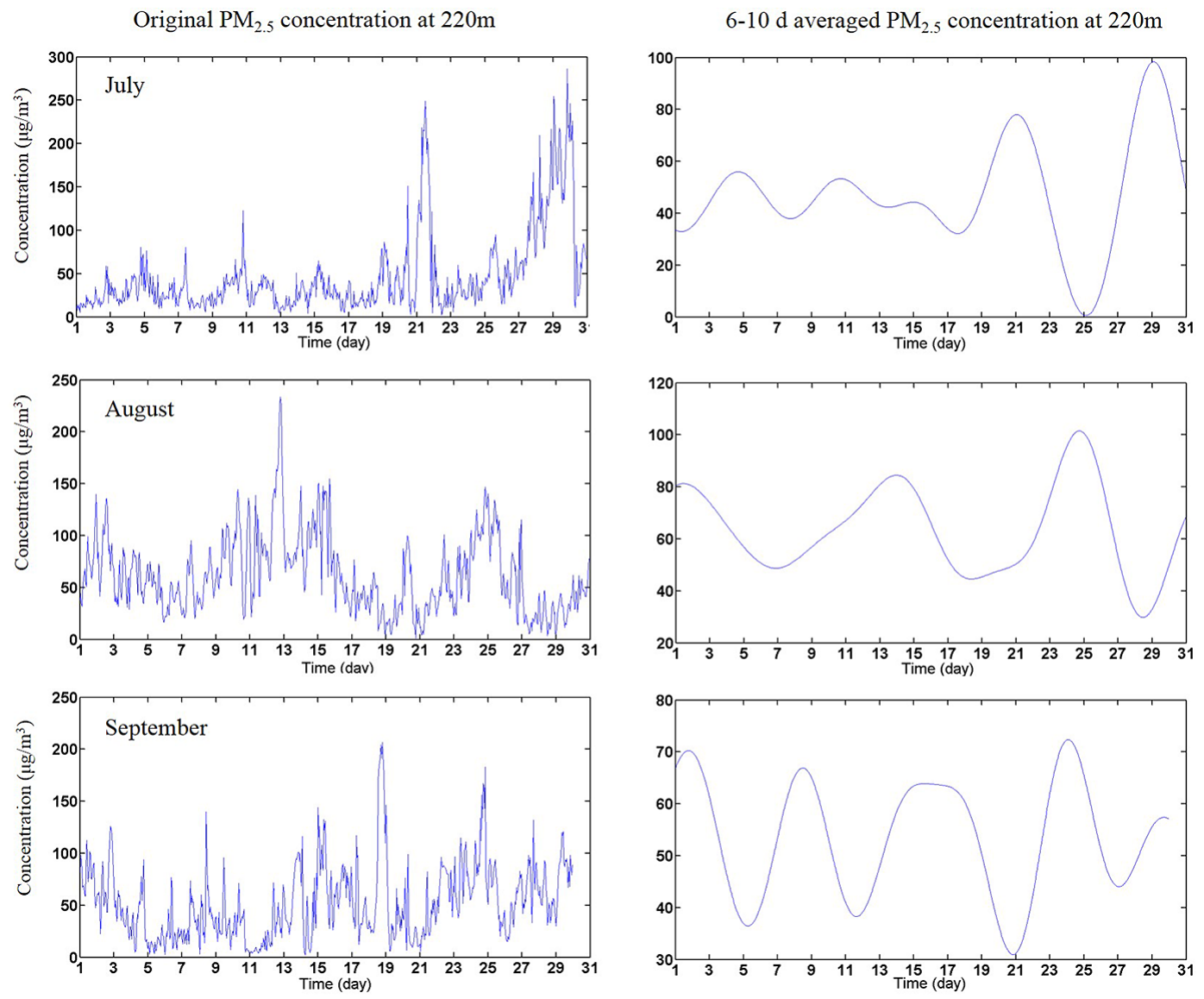

Figure 7. Time series of $\mathrm{PM}_{2.5}$ hourly concentration before and after filtering.

observation errors etc., the original $\mathrm{PM}_{2.5}$ concentration time series exhibits a violent oscillation. Using wavelet transformation, the nocturnal $\mathrm{PM}_{2.5}$ mass concentration time series with the 6-10-day period at the height of $220 \mathrm{~m}$ was extracted from the original time series. After the filtering, impacts from local-scale pollution and diffusion conditions on the short-term fluctuations were considered to be removed. Thus regional-scale pollution and synoptic-scale weather conditions were better represented in the remaining part compared with the original PM concentration time series.

The swings in the $\mathrm{PM}_{2.5}$ concentration data (shown in Fig. 7) mainly resulted from several meteorological processes during the measurement. According to the meteorological data set of the observation station (WMO Id. No. 54517), precipitation processes were recorded during the period of 22-24 July, with the amounts of rainfall ranging from 3.2 to $94.6 \mathrm{~mm}$, followed by a rapid decrease in $\mathrm{PM}_{2.5}$ concentration on 25 July due to consequent cleaning of the air. Then, beginning on $26 \mathrm{July}$, mist paired with calm winds caused a build-up of $\mathrm{PM}_{2.5}$ concentration until 29 July. Similar meteorological processes were reported during the period of 22-25 August, 4-9 and 20-25 September, which resulted in the cycle of cleaning and build-up of air pollutants.
According to the method proposed in this paper, in Tianjin, the averaged regional background $\mathrm{PM}_{2.5}$ concentrations in July, August and September 2009 were $40 \pm 20,64 \pm 17$ and $53 \pm 11 \mu \mathrm{g} \mathrm{m}^{-3}$, respectively.

\section{Summary and conclusions}

It is crucial for studying regional-scale PM pollution and for the development of efficient joint control policy to improve the understanding of the regional background concentration of PM. The purpose of this study is to characterize the regional pollution contribution and to evaluate regional background PM concentration levels. However, regional background concentration can hardly be measured directly. Original PM concentration time series measured on the ground reflect a combination of influence from local pollution and regional-scale pollution. A method to estimate regional background PM concentration is proposed in this paper, based on the vertical variation periodic characteristics of particle mass concentration, the atmospheric boundary layer structure, as well as the vertical distribution of chemical composition and pollution source apportionment. 
Based on a $255 \mathrm{~m}$ meteorological tower, the vertical thermodynamic and dynamic characteristics of the atmospheric boundary layer in Tianjin was observed. The atmospheric layer at $100-150 \mathrm{~m}$ is considered as a transition layer, the variation patterns of temperature and wind speed with height were different compared with the upper and lower layers. A weak vertical gradient in the temperature profile was observed over $100 \mathrm{~m}$. Similarly, a small vertical gradient in wind speed was found over $150 \mathrm{~m}$. The turbulent intensity decreased with increase in height and the descending trend is more obvious from 40 to $120 \mathrm{~m}$ than from 120 to $220 \mathrm{~m}$, which indicates that there were full vertical and horizontal turbulence exchanges below $120 \mathrm{~m}$ of the tower, but relatively weaker exchanges over $120 \mathrm{~m}$. Seasonal averaged nocturnal planetary boundary layer height ranged from 114 to $142 \mathrm{~m}$. The observation height of $220 \mathrm{~m}$ is just outside the NPBL, which indicates that the observation value of PM concentration at $220 \mathrm{~m}$ at night is less affected by local primary sources near the ground and is largely the result of regionalscale pollution.

The vertical distribution of chemical composition in $\mathrm{PM}_{10}$ filter samples also suggests that the impact of primary sources near the ground decreased with height, whereas the impact of secondary sources mainly influenced by regional sources became more prominent. The vertical distribution of percentage was different for various species. Similar percentage levels were observed at the four different heights for $\mathrm{Al}$ and $\mathrm{Si}$. For the $\mathrm{Ca}$ and $\mathrm{EC}$ fractions, higher values were observed at lower sampling sites. The percentages of $\mathrm{NO}_{3}^{-}, \mathrm{SO}_{4}^{2-}$ and $\mathrm{OC}$, and the $\mathrm{OC} / \mathrm{EC}$ ratios were obviously higher at higher sites. Source apportionment for ambient $\mathrm{PM}_{10}$ showed that the percentage contributions of secondary sources obviously increased with height, while the contribution of cement dust decreased with height. PM at higher height obtained more regional contributions, and to some extent it could reflect the characteristics of the regional scale.

The periodic characteristics of $\mathrm{PM}_{2.5}$ mass concentration can reflect different scales of atmospheric processes. In terms of the global wavelet power spectrum of $\mathrm{PM}_{2.5}$ mass concentration, fluctuations of 6-10 days, related to weather processes and regional-scale pollution, were significant at each observation height, while fluctuations with $12-24 \mathrm{~h}$ period, mainly concerned with the daily variation of atmospheric boundary layer and local pollution emissions by human activities in the surface layer, were significant only at ground level. In terms of the local power spectrum, a $12-24 \mathrm{~h}$ period can be observed in a few days on the ground. But with the increase of height, the power of the $12-24 \mathrm{~h}$ period became weaker - only $10-30 \%$ of that on the ground.

According to the above research, the nocturnal $\mathrm{PM}_{2.5}$ mass concentration time series with the 6-10-day period at the measurement height of $220 \mathrm{~m}$ can be regarded as regional background concentration, mainly associated with the regional-scale pollution within $10^{2} \mathrm{~km}$ of the measurement tower. Using wavelet transformation and filtering, the nocturnal $\mathrm{PM}_{2.5}$ mass concentration time series with the 6-10-day period at the height of $220 \mathrm{~m}$ was extracted from the original time series. After removing the impacts from local-scale pollution and diffusion conditions on the short-term fluctuations, regional-scale pollution and synoptic-scale weather conditions were better represented in the remaining part compared with the original PM concentration time series. According to the method proposed in this paper, in Tianjin, the averaged regional background $\mathrm{PM}_{2.5}$ concentrations in July, August and September 2009 were $40 \pm 20,64 \pm 17$ and $53 \pm 11 \mu \mathrm{g} \mathrm{m}^{-3}$, respectively.

We have put forward a new method to estimate the regional background concentration of PM. Background PM concentrations are not constant but vary with space and time. In future research, more analysis on the characteristics of the urban boundary layer, vertical distribution of PM composition and source apportionment in different seasons and meteorological conditions will be done, and background concentration ranges of $\mathrm{PM}_{2.5}$ for given time periods and meteorological conditions will be obtained.

\section{The Supplement related to this article is available online at doi:10.5194/acp-15-11165-2015-supplement.}

Acknowledgements. This work was funded by the Tianjin Science and Technology Projects (14JCYBJC22200), the Science and Technology Support Program (13ZCZDSF02100), and the National Natural Science Foundation of China (NSFC) under Grant No. 41205089 and No. 21207069. We also thank LetPub (www.letpub.com) for linguistic assistance during the preparation of the manuscript.

Edited by: M. Shao

\section{References}

Andreae, M. O., Acevedo, O. C., Araùjo, A., Artaxo, P., Barbosa, C. G. G., Barbosa, H. M. J., Brito, J., Carbone, S., Chi, X., Cintra, B. B. L., da Silva, N. F., Dias, N. L., Dias-Júnior, C. Q., Ditas, F., Ditz, R., Godoi, A. F. L., Godoi, R. H. M., Heimann, M., Hoffmann, T., Kesselmeier, J., Könemann, T., Krüger, M. L., Lavric, J. V., Manzi, A. O., Moran-Zuloaga, D., Nölscher, A. C., Santos Nogueira, D., Piedade, M. T. F., Pöhlker, C., Pöschl, U., Rizzo, L. V., Ro, C.-U., Ruckteschler, N., Sá, L. D. A., Sá, M. D. O., Sales, C. B., Santos, R. M. N. D., Saturno, J., Schöngart, J., Sörgel, M., de Souza, C. M., de Souza, R. A. F., Su, H., Targhetta, N., Tóta, J., Trebs, I., Trumbore, S., van Eijck, A., Walter, D., Wang, Z., Weber, B., Williams, J., Winderlich, J., Wittmann, F., Wolff, S., and Yáñez-Serrano, A. M.: The Amazon Tall Tower Observatory (ATTO) in the remote Amazon Basin: overview of first results from ecosystem ecology, meteorology, trace gas, and aerosol 
measurements, Atmos. Chem. Phys. Discuss., 15, 11599-11726, doi:10.5194/acpd-15-11599-2015, 2015.

Bi, X., Feng, Y., Wu, J., Wang, Y., and Zhu, T.: Source apportionment of $\mathrm{PM}_{10}$ in six cities of northern China, Atmos. Environ., 41, 903-912, 2007.

Brown, S. S., Thornton, J. A., Keene, W. C., Pszenny, A. A. P., Sive, B. C., Dubé, W. P., Wagner, N. L., Young, C. J., Riedel, T. P., Roberts, J. M., VandenBoer, T. C., Bahreini, R., Öztürk, F., Middlebrook, A. M., Kim, S., Hübler, G., and Wolfe, D. E.: Nitrogen, Aerosol Composition, and Halogens on a Tall Tower (NACHTT): Overview of a wintertime air chemistry field study in the front range urban corridor of Colorado, J. Geophys. Res., 118, 8067-8085, doi:10.1002/jgrd.50537, 2013.

Cao, J. J., Lee, S. C., Ho, K. F., Zhang, X. Y., Zou, S. C., Fung, K., Chow, J. C., and Watson, J. G.: Characteristics of carbonaceous aerosol in Pearl River Delta Region, China during 2001 winter period, Atmos. Environ., 37, 1451-1460, 2003.

Cao, J. J., Tie, X. X., Dabberdt, W. F., Tang, J., Zhao, Z. Z., An, Z. S., Shen, Z. X., and Feng, Y. C.: On the potential high acid deposition in northeastern China, J. Geophys. Res., 118, 48344846, doi:10.1002/jgrd.50381, 2013.

Chameides, W. L., Yu, H., Liu, S. C., Bergin, M., Zhou, X., Mearns, L., Wang, G., Kiang, C. S., Saylor, R. D., Luo, C., Huang, Y., Steiner, A.,and Giorgi, F.: Case study of the effects of atmospheric aerosols and regional haze on agriculture: an opportunity to enhance crop yields in China through emission controls, P. Natl. Acad. Sci., 96, 13626-13633, 1999.

Charlson, R. J., Schwartz, S. E., Hales, J. M., Cess, R. D., Coakley Jr., J. A., Hansen, J. E., and Hofmann, D. J.: Climate forcing by anthropogenic aerosols, Science, 255, 423-430, 1992.

Chen, J., Zhao, C. S., Ma, N., Liu, P. F., Göbel, T., Hallbauer, E., Deng, Z. Z., Ran, L., Xu, W. Y., Liang, Z., Liu, H. J., Yan, P., Zhou, X. J., and Wiedensohler, A.: A parameterization of low visibilities for hazy days in the North China Plain, Atmos. Chem. Phys., 12, 4935-4950, doi:10.5194/acp-12-4935-2012, 2012.

Chow, J. C., Watson, J. G., Lowenthal, D. H., Chen, L. W. A., Zielinska, B., Mazzoleni, L. R., and Magliano, K. L.: Evaluation of organic markers for chemical mass balance source apportionment at the Fresno Supersite, Atmos. Chem. Phys., 7, 17411754, doi:10.5194/acp-7-1741-2007, 2007.

Chow, J. C., Watson, J. G., Chen, L.-W. A., Rice, J., and Frank, N. H.: Quantification of $\mathrm{PM}_{2.5}$ organic carbon sampling artifacts in US networks, Atmos. Chem. Phys., 10, 5223-5239, doi:10.5194/acp-10-5223-2010, 2010.

Chow, J. C., Watson, J. G., Robles, J., Wang, X. L., Chen, L. W. A., Trimble, D. L., Kohl, S. D., Tropp, R. J., and Fung, K. K.: Quality assurance and quality control for thermal/optical analysis of aerosol samples for organic and elemental carbon, Anal. Bioanal. Chem., 401, 3141-3152, doi:10.1007/s00216-011-5103-3, 2011.

Ding, G., Chen, Z., Gao, Z., Yao, W., Li, Y., Cheng, X., Meng, Z., Yu, H., Wong, K., Wang, S., and Miao, Q.: The vertical structure and its dynamic characteristics of $\mathrm{PM}_{10}$ and $\mathrm{PM}_{2.5}$ in lower atmosphere in Beijing city, Sci. China Ser. D, 35, 31-44, 2005.

Dockery, D. W., Pope, C. A., Xu, X. P., Spengler, J. D., Ware, J. H., Fay, M. E., Ferris Jr., B. G., and Speizer, F. E.: An association between air pollution and mortality in 6 United States cities, N. Engl. J. Med., 329, 1753-1759, 1993.
Dreyer, A. and Ebinghaus, R.: Poly fluorinated compounds in ambient air from ship- and land-based measurements in northern Germany, Atmos. Environ., 43, 1527-1535, 2009.

Englert, N.: Fine particles and human health-a review of epidemiological studies, Toxicol. Lett., 149, 235-242, 2004.

Foken, T. and Nappo, C. J.: Micrometeorology, Springer, Berlin, 308 pp., 2008.

Gu, J. X., Bai, Z. P., Li, W. F., Wu, L. P., Liu, A. X., Dong, H. Y., and Xie, Y. Y.: Chemical composition of $\mathrm{PM}_{2.5}$ during winter in Tianjin, China, Particuology, 9, 215-221, 2011.

Guinot, B., Roger, J. C., Cachier, H., Wang, P. C., Bai, J. $\mathrm{H}$., and $\mathrm{Yu}$, T.: Impact of vertical atmospheric structure on Beijing aerosol distribution, Atmos. Environ., 40, 5167-5180, doi:10.1016/j.atmosenv.2006.03.051, 2006.

Guo, S., Hu, M., Guo, Q., Zhang, X., Schauer, J. J., and Zhang, R.: Quantitative evaluation of emission controls on primary and secondary organic aerosol sources during Beijing 2008 Olympics, Atmos. Chem. Phys., 13, 8303-8314, doi:10.5194/acp-13-83032013, 2013.

Hagler, G. S. W., Bergin, M. H., Salmon, L. G., Yu, J. Z., Wan, E. C. H., Zheng, M., Zeng, L. M., Kiang, C. S., Zhang, Y. H., Lau, A. K. H., and Schauer, J. J.: Source Areas and Chemical Composition of Fine Particulate Matter in the Pearl River Delta Region of China, Atmos. Environ., 40, 3802-3815, 2006.

Han, S. Q., Bian, H., Tie, X. X., Xie, Y. Y., Sun, M. L., and Liu, A. X.: Impact of nocturnal planetary boundary layer on air pollutants: Measurements from a $250 \mathrm{~m}$ tower over Tianjin, China, J. Hazard. Mater., 162, 264-269, 2009.

Han, X., Zhang, M. G., Tao, J. H., Wang, L. L., Gao, J., Wang, S. L., and Chai, F. H.: Modeling aerosol impacts on atmospheric visibility in Beijing with RAMS-CMAQ, Atmos. Environ., 72, 177-191, 2013.

Heintzenberg, J., Birmili, W., Theiss, D., and Kisilyakhov, Y.: The atmospheric aerosol over Siberia, as seen from the $300 \mathrm{~m}$ ZOTTO tower, Tellus B, 60, 276-285, doi:10.1111/j.16000889.2007.00335.x, 2008.

Heintzenberg, J., Birmili, W., Seifert, P., Panov, A., Chi, X., and Andreae, M. O.: Mapping the aerosol over Eurasia from the Zotino Tall Tower, Tellus B, 65, 1-13, doi:10.3402/tellusb.v65i0.20062, 2013.

Hopke, P. K.: Indoor air pollution: radioactivity, Trends Anal. Chem., 4, 5-6, 1985.

Hu, W. W., Hu, M., Yuan, B., Jimenez, J. L., Tang, Q., Peng, J. F., Hu, W., Shao, M., Wang, M., Zeng, L. M., Wu, Y. S., Gong, Z. H., Huang, X. F., and He, L. Y.: Insights on organic aerosol aging and the influence of coal combustion at a regional receptor site of central eastern China, Atmos. Chem. Phys., 13, 10095-10112, doi:10.5194/acp-13-10095-2013, 2013.

Husar, R. B., Holloway, J. M., Patterson, D. E., and Wilson, W. E.: Spatial and temporal pattern of eastern US haziness: a summary, Atmos. Environ., 15, 1919-1928, 1981.

Hwang, I., Hopke, P. K., and Pinto, J. P.: Source apportionment and spatial distributions of coarse particles during the regional air pollution study, Environ. Sci. Technol., 42, 3524-3530, 2008.

Kim, S. W., Yoon, S. C., Won, J. G., and Choi, S. C.: Ground-based remote sensing measurements of aerosol and ozone in an urban area: A case study of mixing height evolution and its effects on Ground-level ozone concentrations, Atmos. Environ., 41, 7069$7081,2007$. 
Krudysz, M., Moore, K., Geller, M., Sioutas, C., and Froines, J.: Intra-community spatial variability of particulate matter size distributions in Southern California/Los Angeles, Atmos. Chem. Phys., 9, 1061-1075, doi:10.5194/acp-9-1061-2009, 2009.

Lagudu, U. R. K., Raja, S., Hopke, P. K., Chalupa, D. C., Utell, M. J., Casuccio, G., Lersch, T. L., and West, R. R.: Heterogeneity of Coarse Particles in an Urban Area, Environ. Sci. Technol., 45, 3188-3296, 2011.

Langford, A. O., Senff, C. J., Banta, R. M., Hardesty, R. M., Alvarez, R. J., Sandberg, S. P., and Darby, L. S.: Regional and local background ozone in Houston during Texas Air Quality Study 2006, J. Geophys. Res., 114, D00F12, doi:10.1029/2008JD011687, 2009.

Lena, F. and Desiato, F.: Intercomparison of nocturnal mixing height estimate methods for urban air pollution modeling, Atmos. Environ., 33, 2385-2393, 1999.

Li, S. M.: A concerted effort to understand the ambient particulate matter in the Lower Fraser Valley: the Pacific 2001 Air Quality Study, Atmos. Environ., 38, 5719-5731, 2004.

Liu, P. F., Zhao, C. S., Göbel, T., Hallbauer, E., Nowak, A., Ran, L., Xu, W. Y., Deng, Z. Z., Ma, N., Mildenberger, K., Henning, S., Stratmann, F., and Wiedensohler, A.: Hygroscopic properties of aerosol particles at high relative humidity and their diurnal variations in the North China Plain, Atmos. Chem. Phys., 11, 3479-3494, doi:10.5194/acp-11-3479-2011, 2011.

Liu, W. X., Coveney, R. M., and Chen, J. L.: Environmental quality assessment on a river system polluted by mining activities, Appl. Geochem., 18, 749-764, 2003.

McKendry, I. G., Stahl, K., and Moore, R. D.: Synoptic sea-level pressure patterns generated by a general circulation model: comparison with types derived from NCEP/NCAR re-analysis and implications for downscaling, Int. J. Climatol., 26, 1727-1736, 2006.

Menichini, E., Iacovella, N., Monfredini, F., and Turrio-Baldassarri, L.: Atmospheric pollution by PAHs, PCDD/Fs and PCBs simultaneously collected at a regional background site in central Italy and at an urban site in Rome, Chemosphere, 69, 422-434, 2007.

Pal, S., Lee, T. R., Phelps, S., and De Wekker, S. F. J.: Impact of atmospheric boundary layer depth variability and wind reversal on the diurnal variability of aerosol concentration at a valley site, Sci. Total Environ., 496, 424-434, doi:10.1016/j.scitotenv.2014.07.067, 2014.

Pérez, N., Pey, J., Castillo, S., Viana, M., Alastuey, A., and Querol, $\mathrm{X}$.: Interpretation of the variability of levels of regional background aerosols in the Western Mediterranean, Sci. Total Environ., 407, 527-540, 2008.

Schmid, H. P.: Footprint modeling for vegetation atmosphere exchange studies: a review and perspective, Agr. Forest Meteorol., 113, 159-183, 2002.

Schwartz, S. E.: The white house effect - shortwave radiative forcing of climate by anthropogenic aerosols: an overview, J. Aerosol Sci., 27, 359-382, 1996.

Seibert, P., Beyrich, F., Gryning, S. E., Joffre, S., Rasmussen, A., and Tercier, P.: Review and intercomparison of Operational methods for the determination of the mixing height, Atmos. Environ., 34, 1001-1027, 2000.

Strader, R., Lurmann, F., and Pandis, S. N.: Evaluation of secondary organic aerosol formation in winter, Atmos. Environ., 33, 48494863, 1999.
Shao, M., Tang, X. Y., Zhang, Y. H., and Li, W. J.: City clusters in China: air and surface water pollution, Front. Ecol. Environ., 4, 353-361, 2006.

Shi, G. L., Li, X., Feng, Y. C., Wang, Y. Q., Wu, J. H., Li, J., and Zhu, T.: Combined source apportionment, using positive matrix factorization-chemical mass balance and principal component analysis/multiple linear regression-chemical mass balance models, Atmos. Environ., 43, 2929-2937, 2009.

Shi, G. L., Tian, Y. Z., Zhang, Y. F., Ye, W. Y., Li, X., Tie, X. X., Feng, Y. C., and Zhu, T.: Estimation of the concentrations of primary and secondary organic carbon in ambient particulate matter: Application of the CMB-Iteration method, Atmos. Environ. 45, 5692-5698, 2011.

Tchepel, O., Costa, A. M., Martins, H., Ferreira, J., Monteiro, A., Miranda, A. I., and Borrego, C.: Determination of background concentrations for air quality models using spectral analysis and filtering of monitoring data, Atmos. Environ., 44, 106-114, 2010.

Tian, Y. Z., Wu, J. H., Shi, G. L., Wu, J. Y., Zhang, Y. F., Zhou, L. D., Zhang, P., and Feng, Y. C.: Long-term variation of the levels, compositions and sources of size-resolved particulate matter in a megacity in China, Sci. Total Environ., 463, 462-468, 2013.

Tie, X. X., Brasseur, G. P., Zhao, C. S., Granierc, C., Massiea, S., Qin, Y., Wang, P. C., Wang, G., Yang, P. C., and Richter, A.: Chemical characterization of air pollution in Eastern China and the Eastern United States, Atmos. Environ., 40, 2607-2625, 2006.

Tie, X. X., Wu, D., and Brasseur, G. P.: Lung cancer mortality and exposure to atmospheric aerosol particles in Guangzhou, China, Atmos. Environ., 43, 2375-2377, 2009.

Torrence, C. and Compo, G. P.: A practical guide to wavelet analysis, B. Am. Meteorol. Soc., 79, 61-78, 1998.

USEPA (US Environmental Protection Agency): EPA CMB8.2 User's Manual, Office of Air Quality Planning and Standards, Research Triangle Park NC 27711, 2004.

Watson, J. G., Cooper, J. A., and Huntzicker, J. J.: The effective variance weighting for least squares calculations applied to the mass balance receptor model, Atmos. Environ., 18, 1347-1355, 1984.

Watson, J. G., Zhu, T., Chow, J. C., Engelbrecht, J., Fujita, E. M., and Wilson, W. E.: Receptor modeling application framework for particle source apportionment, Chemosphere, 49, 1093-1136, 2002.

Watson, J. G., Chen, L.-W. A., Chow, J. C., Doraiswamy, P., and Lowenthal, D. H.: Source apportionment: findings from the U.S supersites program, J. Air Waste Manage., 58, 265-288, 2008.

WHO (World Health Organization): Glossary on air pollution, WHO Regional Publications, Eur. Series No. 9, Regional Office for Europe, Copenhagen, 1980.

Wongphatarakul, V., Friedlander, S. K., and Pinto, J. P.: A comparative study of $\mathrm{PM}_{2.5}$ ambient aerosol chemical databases, Environ. Sci. Technol., 32, 3926-3934, 1998.

Zeng, Y. and Hopke, P. K.: A study of the sources of acid precipitation in Ontario, Canada, Atmos. Environ., 23, 1499-1509, 1989.

Zhu, T., Shang, J., and Zhao, D. F.: The roles of heterogeneous chemical processes in the formation of an air pollution complex and gray haze, Sci. China Ser. B, 54, 145-153, doi:10.1007/s11426-010-4181-y, 2011. 